\title{
Chilaiditi sendromu ve mide kanseri
}

\author{
Chilaiditi's syndrome with gastric cancer
}

\author{
Onur BAŞ ${ }^{1}$, Fuad MUSTAFAYEV², Cavanşir VAHABOV² \\ Hacettepe Üniversitesi Tıp Fakültesi, 'İç Hastalıkları Anabilim Dalı, ${ }^{2}$ Gastroenteroloji Bilim Dalı, Ankara
}

Karın ağrısı, nefes darlığı nedeniyle acil servise başvuran 83 yaşındaki kadın hastanın rektal tuşesinde melena saptanması üzerine yapılan endoskopide mide antrumundaki ülsere adeno kanser tanısı konuldu. Hastaya malignite evrelemesi amacıyla abdomen bilgisayarlı tomografi çekildi. Mide duvarı kalınlığı dışında, Chilaiditi belirtisi de saptandı (Resim 1,2).

Chilaiditi belirtisi kolon ve/veya ince barsağın karaciğer ve diyafragma arasına transpozisyonu olarak adlandırılır. Toplumda görülme sıklığı \%0.1-\%1 arasındadır. Erkeklerde ve yaşlılarda daha sık görülür $(1,2)$. Genelde tesadüfen saptanır ve hastalar çoğunlukla asemptomatiktir. Sağ üst kadran ağrısı, nefes darlığı, kabızlık gibi semptomlarla birlikteliğinde Chilaiditi sendromu olarak adlandırılır. En sık

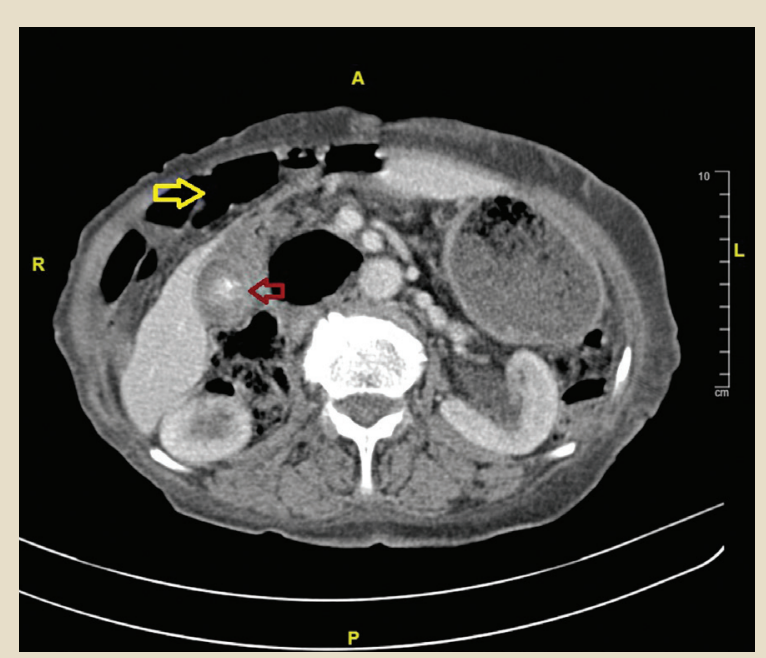

Resim 1. Kırmızı ok; mide antrumunu, sarı ok; karaciğerin önündeki kolon segmentini göstermektedir.

\section{KAYNAKLAR}

1. Sanyal K, Sabanathan K. Air below the right diaphragm: Chilaiditi sign. Emerg Med J 2008;25:300.

2. Tzimas T, Baxevanos G, Akritidis N. Chilaiditi's sign. Lancet 2009; 373:836. bilinen önemi diyafragma altındaki gaz görünümü nedeniyle pnömoperitoneum ile karıştırılarak gereksiz cerrahi girişimlere neden olabilmesidir.

Chilaiditi belirtisinin bazı hastalıklar ile birlikte olduğu da bildirilmiştir. Literatürde kolon volvulusu, kronik obstrüktif akciğer hastalığı, siroz, atrofik veya pitotik karaciğer varlığı, frenik sinir hasarı ve obezitenin Chilaiditi belirtisi ile beraber görüldüğü vaka sunumları mevcuttur. Chilaiditi belirtisinin kolon kanseri ile beraber görüldüğü vakalar (3) bildirilmiştir. Bizim hastamızda mide kanseri ile birliktelik söz konusudur.

Karaciğer pitozu, sirozu gibi bazı patolojilerdeki gibi neden-sonuç ilişkisi kurulamasa da, tümörle birlikte olabileceği de unutulmamalıdır.

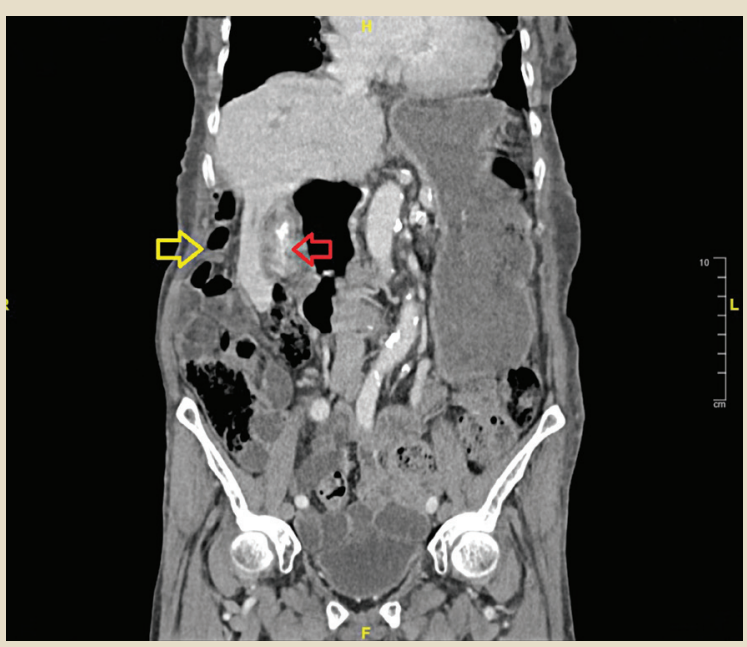

Resim 2. Kırmızı ok; mide antrumunu, sarı ok; karaciğerin önündeki kolon segmentini göstermektedir.

3. Yagnik VD. Chilaiditi syndrome with carcinoma rectum: rare entity. Saudi J Gastroenterol 2011;17:85-6.

Baş O, Mustafayev F, Vahabov C. Chilaiditi's syndrome with gastric cancer. The Turkish Journal of Academic Gastroenterology 2019;18:1. DOI: 10.17941/ agd.544137

Geliş Tarihi: 11.01.2019 • Kabul Tarihi: 13.01.2019 